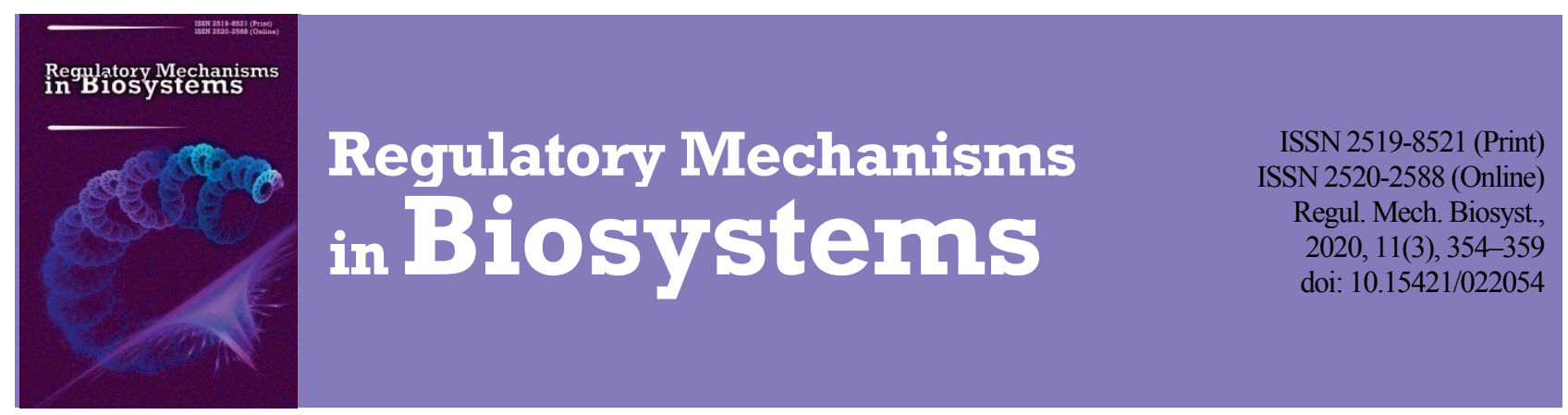

\title{
The effect of miR-101 on the memory of rats with a model of Alzheimer's disease
}

\author{
O. G. Berchenko, N. O. Levicheva, D. O. Bevzyuk, V. V. Sokolik \\ Institute of Neurology, Psychiatry and Narcology, Kharkiv, Ukraine
}

Article info

Received 15.07.2020

Received in revised form 23.08.2020

Accepted 25.08.2020

Institute of Neurology, Psychiatry and Narcology Academy Pavlov st., 46 , Kharkov, 61068, Ukraine Tel.: + 38-095-055-38-80. E-mail:

berchenko.olga@ukr.net

\section{Introduction}

One of the first symptoms of Alzheimer's disease is the irreversible deterioration of memory up to dementia. In patients, Alzheimer's dementia is distinguished, which is due to the occurrence and course of cerebral amyloidosis (formation of a local excess of $\beta$-amyloid peptide (A $\beta)$ aggregates in the foci of cholinergic neurons of the neocortex and hippocampus). The presence of a long asymptomatic period is a feature of neurodegenerative pathology of Alzheimer's disease. During this period, the manifestations of specific disorders of memory and cognitive functions are compensated by the mechanisms of the brain (Purdenko, 2014). It has been shown that the neocortex and hippocampus (Insel \& TakeharaNishiuchi, 2013; Huijgen \& Samson, 2015) are structures that provide mechanisms for the formation of different types of memory: emotional, working, spatial (Silachjov et al., 2008; Antunes \& Biala, 2012; Grigorchuk, 2013). In patients with Alzheimer's disease, it is the neurons of the neocortex and hippocampus that suffer the most from the toxicity of $A \beta$ oligomers, which subsequently form senile plaques characteristic of amyloidogenic pathology (Mukhin, 2013). Increased forgetting of available information as an early manifestation of the disease is due to a decrease in the amount and time of information retention in working memory. Violation of the mechanisms of consolidation of memory traces is observed already in the clinical stage of Alzheimer's disease.

Currently, the clinical treatment protocols for Alzheimer's disease prefer symptomatic treatment with central acetylcholinesterase inhibitors, cholinomimetics and NMDA receptor antagonists in compensatory therapy, as well as neuroprotection with nootropics, which aims to preserve and maintain life of neurons (Bullock, 2002). However, such a strategy is not able to prevent the constantly progressing dementia, but only to delay it. Therefore, one of the leading strategies for the treatment of Alzheimer's disease is the development of approaches that do not affect the symptoms, but the pathological mechanisms of cerebral amyloidosis. Individual $\gamma$-secretase modulators (an enzyme that secretes $\beta$-amyloid peptides from $\mathrm{A} \beta$ precursor protein (A $\beta \mathrm{PP})$ during amyloidogenic processing) have been shown to be able to specifically inhibit its activity against A $\beta P P$ without interfering with the metabolism of other substrates of this enzyme (Raven et al., 2017). It has been experimentally found that anti-inflammatory therapy, such as curcumin, has a positive effect not only on chronic inflammation, which invariably accompanies the course of amyloidosis, but also directly inhibits the excessive formation of $\beta$-amyloid peptides (Sokolik et al., 2017).

Gene therapy that regulates or blocks overexpression of a single gene at the posttranscriptional level by means of the corresponding miRNA has proved to be promising (Wang et al., 2012; Shaik et al., 2018). It is shown that miR-101 is able to specifically interact with its "seed" site with the template RNA of the $\mathrm{A} \beta$ precursor protein and, thus, repress the expression of the A $\beta$ PP gene (Francis et al., 2010). However, since their discovery in 1998, miRNAs have not lived up to the expectations of pharmaceutical companies (Eisenstein, 2019), because the problem of targeted delivery of these molecules to target organs and body tissues has not been solved.

Upon introduction into the bloodstream or subcutaneously, the bulk of the miRNA ended up in the liver regardless of the type of carrier, whether liposomes, liproteins, N-acetylgalactosamine (GalNAc), etc. To solve the problem of direct delivery of miR-101 to the central nervous system, in addition to direct traumatic injections into the cerebrospinal fluid, you can use its intranasal course administration in liposomal form.

The aim of the study is to explore the influence intranasal administration of liposomal miR-101 on memory processes in late adult rats in experimental modeling of Alzheimer's disease. 


\section{Materials and methods}

Research design. Procedures with experimental animals were approved by the Commission on Ethics and Deontology of SI "Institute of Neurology, Psychiatry and Addiction of the National Academy of Medical Sciences of Ukraine" and performed in accordance with the General Ethical Principles of Animal Experiments (Kyiv, 2011), "The procedure for conducting experiments and experiments on animals by scientific institutions" (No 249 of 01.03.2012), the Law of Ukraine "On protection of animals from cruel treatment” (№ 3447-IV of 21.02.2006). The study was conducted on a general group of male rats 15-16 months of age, weighing $300-500 \mathrm{~g}(\mathrm{n}=33)$. Animals were randomly divided into two groups: experimental $(n=17)$ and comparison group $(n=16)$.

Simulation of Alzheimer's disease in all rats was performed by stereotactic administration of aggregated A $\beta 40$ Human (China Peptides Co, China), in the left hippocampus at a dose of $\overline{1} 5 \mathrm{nmol} / \mathrm{L} \beta$-amyloid peptide 40 , which was pre-dissolved in double-distilled water and aggregate during the day (Fig. 1). Large coarse conglomerates of $A \beta 40$ were dispersed by ultrasound and sterilized immediately before administration. The volume of the injected suspension of $A \beta 40$ in aggregate form was $10 \mu \mathrm{L}$, the rate of injection through the needle of the chromatographic syringe $0.03 \mu \mathrm{L} / \mathrm{s}$, the duration of administration -5 minutes. Stereotactic coordinates of the hippocampus were determined from brain maps of rats Fifkova and Marshall, as quoted by Buresh et al. (1962), which corresponded to the distance from the point of intersection of the sagittal suture with bregma: $\mathrm{F}=2 \mathrm{~mm}, \mathrm{~L}=2 \mathrm{~mm}, \mathrm{H}=3.5 \mathrm{~mm}$. The operations were performed under general anesthesia under intra-abdominal injection of sodium thiopental solution $(50 \mathrm{mg} / \mathrm{kg})$.

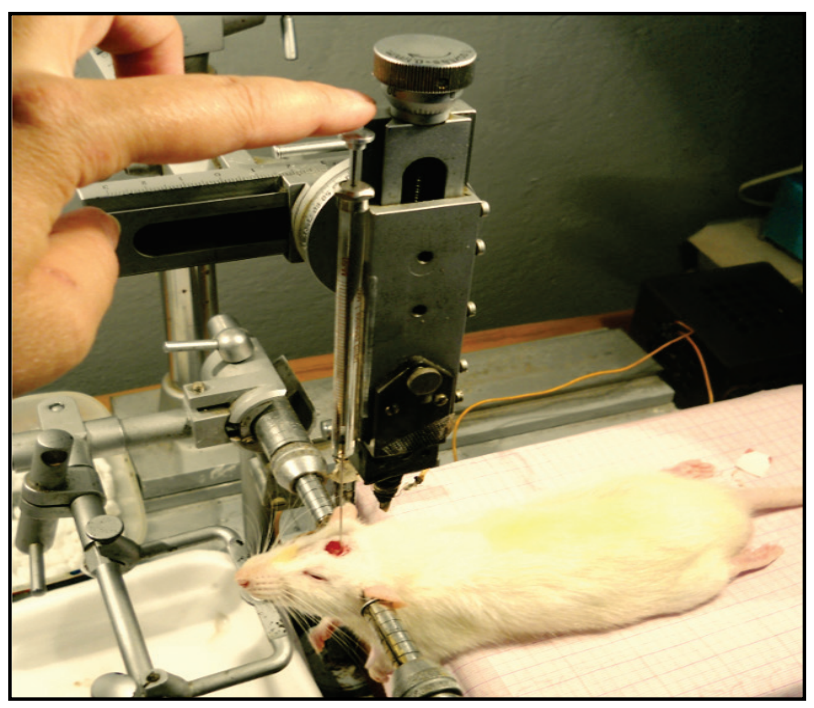

Fig. 1. Stereotactic administration of $\beta$-amyloid peptide 40 aggregates in the left hippocampus of rats

To study the processes of memory recovery in animals with a model of Alzheimer's disease we performed intranasal administration of liposomal miR-101 (OOO "NPF Sintal", RF) to rats of the experimental group for 10 days. The liposomal form of miR-101 was obtained by the method of lipid films (Shulga, 2014). For 10 sessions of administration, each animal of the experimental group received $2.5 \times 10^{14}$ molecules of miR-101, the volume of a single portion of liposomal miRNA was $20 \mu \mathrm{L}$. The effect of miR-101 was chosen because it is a key operator of matrix RNA (mRNA) function for the $\mathrm{A} \beta$ precursor protein $(\mathrm{A} \beta \mathrm{PP})$ due to the formation of a complex with its subsequent deactivation and therefore able to inhibit A $\beta P P$ synthesis and amyloidogenic processing of the latter (Vilardo et al., 2010; Amakiri et al., 2019). Animals in the reference group did not receive liposomal miR-101.

Neuroethological testing of working memory. Working memory was characterized based on the natural ability of rats to learn something new (reaction to the novelty of the stimulus). We evaluated the ability of animals to recognize new objects based on the detection of changes in the physical properties of the object and the fixation of these characteristics (memorization) (Abdurasulova et al., 2019). The test of working memory was as follows. Two days before testing, the rat was placed in an experimental cage for $10 \mathrm{~min}$ to adapt to the experimental conditions. On the $3 \mathrm{rd}$ day, the animal was placed in the center of the cage in front of two identical objects A1 and A2 (identical wooden cubes measuring $2.0 \times 4.5 \times$ $3.0 \mathrm{~cm}$; located at a distance of $15 \mathrm{~cm}$ from each other) and for $5 \mathrm{~min}$ we recorded the duration of the research reaction: the total time of sniffing objects at a distance of less than $2 \mathrm{~cm}$ or touching them with the nose/foot (training phase). On day 4, a similar procedure was performed (test phase), with object $\mathrm{A} 2$ being replaced by any new object B (B1, B2, B3 or B4). Namely: object B1 - a rectangular parallelepiped measuring $1.0 \times 8.0 \times$ $1.5 \mathrm{~cm}$, object $\mathrm{B} 2-$ a triangular pyramid measuring $4.0 \times 5.0 \mathrm{~cm}$, object B3 - a sphere with a diameter of $5 \mathrm{~cm}$, object B4 - a truncated cone measuring $3.5 \times 5.0 \mathrm{~cm}$. We recorded the study time of the new object (B1, $\mathrm{B} 2, \mathrm{~B} 3$ or B4) and the familiar object A1, and calculated the percentage of discrimination, which was the time spent on the study of the new object, relative to the total study time of both objects in the testing phase (TzyyNan \& Yi-Ping, 2014; Gulljaev et al., 2017). Working memory metrics was determined in the initial state, on the 5-6th day after intrahypocampal administration of $A \beta 40$ aggregates, on the 8-9th day of intranasal course of liposomal miR-101.

Exploration of spatial (short-term and long-term) memory in the Barnes labyrinth. A Barnes' labyrinth was used to study spatial memory (Fig. 2). At the heart of the Barnes maze technique is the physiologically determined desire of rats to avoid brightly lit open spaces and the search for a protective chamber with a focus on the configuration of distal visual signals located around the test area (Attar et al., 2013; Sysoev, 2019). The Barnes labyrinth includes a round platform $(121 \mathrm{~cm}$ in diameter $)$ with 16 evenly spaced holes ( $9 \mathrm{~cm}$ in diameter) that is raised $85 \mathrm{~cm}$ above the floor. The holes are $7.5 \mathrm{~cm}$ from the edge of the platform. Under one of the holes is a protective chamber - a plastic box measuring $24 \times 15 \mathrm{~cm}$. The surface of the platform is equipped with a bright light source $(150 \mathrm{~W})$, which is at a height of $40 \mathrm{~cm}$ from the middle of the maze. Orientations of animals in space served as visual signals - large geometric shapes located on both sides of the labyrinth. The starting area for the experimental animal was a cylinder with a diameter of $20 \mathrm{~cm}$.

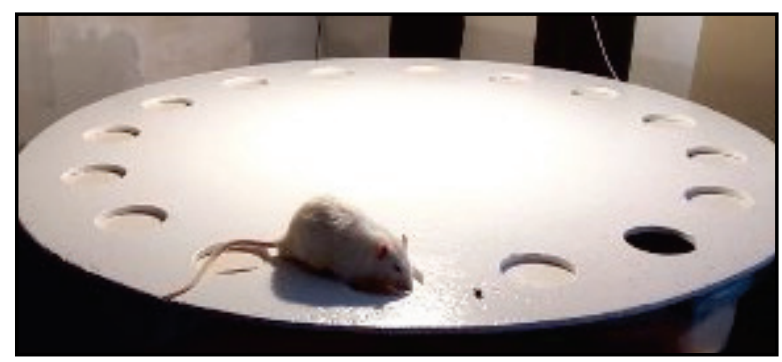

Fig. 2. Barnes labyrinth for the study of spatial memory in experimental animals

In the Barnes labyrinth, the animal went through three stages: adaptation, training and testing of short-term and long-term memory. During adaptation, the animal was placed in a cylinder located in the center of the platform and the light was turned on. After 10 minutes, the cylinder was lifted and the animal was directed to the protective chamber. If the rat did not enter the protective chamber for $2 \mathrm{~min}$, it was forcibly directed to the hole with the protective chamber. As soon as the animal was in the protective chamber, the light was turned off and the animal was left inside the box for another 2 minutes. During training, the animal was also placed in a cylinder in the starting area and the light turned on. After 10 minutes, the cylinder was raised and the animal was given the opportunity to see the maze for 3 minutes. In the Barnes labyrinth we recorded the time of successful search for a hole with a protective chamber and the trajectory of movement. The study was stopped after the rat entered the protective chamber, in which the animal was left for another 1 minute. We conducted 4 studies per day with an interval between studies of $15 \mathrm{~min}$ for 4 days. Testing of short-term memory was performed on the 5 th day with a closed hole in the protective chamber, 24 hours after the last day of training. The procedure was performed similarly to the training process, but the animal was allowed to explore the maze only for 90 seconds. 
We determined whether the rat remembered the location of the protective chamber or not. The time of finding the protective chamber, the number of approaches to it, the time spent near the protective chamber, the trajectory of the rat, autonomic reactions were recorded. The same testing was repeated on the 11th day after intrahypocampal administration of $A \beta 40$ aggregates (Alzheimer's disease model) and after the 10th day of intranasal administration of liposomal miR-101 (in the experimental group) and on the 26th day of the Alzheimer's disease model without treatment (in the comparison group). To do this, rats were retrained to search for a protective chamber, but located in a different location than in previous tests.

Evaluation of long-term spatial memory was performed similarly to short-term, only without any prior training. All parameters in experimental animals were recorded in the initial state, on the 7th and 21st day after intrahypocampal administration of $A \beta 40$ aggregates and after a course (10 days) of intranasal administration of liposomal miR-101.

Testing of emotional memory by the method of conditioned-reflex emotional reaction of avoidance. The study of the features of emotional memory was performed using the technique of conditioned-reflex emotional response avoidance (CRERA) (Bevziuk et al., 2020). The emotional conditioned reaction of avoidance was performed in a specially equipped chamber divided into two parts by a partition with a window. Voltage was applied to the floor electrodes in this chamber (threshold of nociceptive pacing stimulation from 3.0 to $3.5 \mathrm{~V}$ ); the current was turned on by closing the contacts. The conditional signal for the rat was the sound of a metronome with a frequency of $120 \mathrm{~min}^{-1}$, and its unconditional reinforcement was carried out by electric current. The animals in the chamber were given a conditional signal, after which the next $10 \mathrm{~s}$ of sound was combined with unconditional reinforcement. If during this time the rat did not move to another part of the chamber, the metronome was turned off, and electric stimulation was carried out for another $5 \mathrm{~s}$. The duration of the inter-signal period was chosen randomly in the range of 2 to 3 minutes to prevent the development of a conditioned reflex in the animal for a while. They were presented with no more than 6 combinations of conditional signal and unconditional reinforcement per day. The conditioned reflex was considered to be produced if the rat moved to another part of the chamber during one experimental day during the action of the conditioned signal at least 5 times in a row. The share of such behavioral responses as extrasignal, signaling, avoidance responses, sample responses, and autonomic responses that accompany CRERA production was expressed as a percentage of the number of conditional signal combinations with unconditional reinforcement presented at individual stages of the experiment on average. Assessment of memory function was performed before the introduction of A $\beta 40$ aggregates, on the 5th day of Alzheimer's disease simulation and after 10 days of intranasal administration of liposomal miR-101 or without treatment.

Statistical data processing was performed using the program Statistica 6.0 (Statsoft Inc., USA, 2001). After pre-establishing the normality of the data distribution in each group, the mean and standard deviation $(x \pm S D)$ were calculated. Single-factor dispersion analysis ANOVA was used to detect statistically significant differences between groups. Differences were considered significant at $\mathrm{P}<0.05$ using the Tukey test.

\section{Results}

Working memory. Administration to rats of aggregated $\beta$-amyloid peptide 40 in the hippocampus led to a gradual violation of the mechanisms of working memory. On the 5th day after administration of the neurotoxin, the rats' information about the experience of recognizing familiar objects was stored. The study time of the same familiar subjects did not differ from the original data. However, the study time of the new unfamiliar stimulus B2 (triangular pyramid) decreased compared to baseline (Table 1).

On the 16th day after administration of the neurotoxin, there was a deterioration in the recognition of identical objects. The time of their study was significantly $(\mathrm{P}<0.05)$ different from the original data. Interest in the unfamiliar object B3 (bullet) decreased. The study time was significantly $(\mathrm{P}<0.05)$ decreased compared to baseline and values after the 5 th day of neurotoxin administration (Table 1). The discrimination rate was $53 \%$ vs. $65 \%$ of baseline values (Fig. 3).

\section{Table 1}

Time of study of familiar and unfamiliar objects in rats after intrahypocampal administration of $\beta$-amyloid peptide 40 aggregates and intranasal administration of liposomal miR-101 (s, $\mathrm{x} \pm \mathrm{SD}$ )

\begin{tabular}{|c|c|c|c|c|c|}
\hline \multicolumn{2}{|c|}{$\begin{array}{l}\text { Characteristics } \\
\text { of the group }\end{array}$} & $\begin{array}{l}\text { Output } \\
\text { data }\end{array}$ & $\begin{array}{c}\text { Model of } \\
\text { Alzheimer's } \\
\text { disease }\end{array}$ & $\begin{array}{l}\text { The model of the } \\
\text { disease Alzhei- } \\
\text { mer's without } \\
\text { treatment }\end{array}$ & $\begin{array}{c}\text { Intranasal } \\
\text { liposomal } \\
\text { administration } \\
\text { miR-101 in } \\
\text { Alzheimer's } \\
\text { disease }\end{array}$ \\
\hline \multicolumn{2}{|c|}{ Date } & Oth day & 5-6th day & 16-17th days & 16-17th days \\
\hline \multicolumn{2}{|c|}{ Group name } & common & common & comparison & experimental \\
\hline \multicolumn{2}{|c|}{$\mathrm{n}$} & 33 & 33 & 16 & 17 \\
\hline \multirow{2}{*}{$\begin{array}{l}\text { Identical } \\
\text { objects }\end{array}$} & A1 & $20.2 \pm 2.5$ & $10.0 \pm 2.0^{\mathrm{a}}$ & $12.8 \pm 2.5^{\mathrm{a}}$ & $8.2 \pm 2.8^{\mathrm{a}}$ \\
\hline & $\mathrm{A} 2$ & $21.6 \pm 2.3$ & $9.8 \pm 1.7^{\mathrm{a}}$ & $22.7 \pm 4.8^{\mathrm{b}}$ & $8.9 \pm 2.6^{\mathrm{ac}}$ \\
\hline \multirow{5}{*}{$\begin{array}{l}\text { Familiar } \\
\text { and } \\
\text { unfamiliar } \\
\text { objects }\end{array}$} & A1 & $9.6 \pm 1.7$ & $10.1 \pm 1.3$ & $12.3 \pm 4.5$ & $13.2 \pm 1.7$ \\
\hline & B1 & $23.5 \pm 3.1^{\mathrm{d}}$ & - & - & - \\
\hline & $\mathrm{B} 2$ & - & $16.2 \pm 0.8^{\mathrm{a}, \mathrm{d}}$ & - & - \\
\hline & B3 & - & - & $11.2 \pm 1.8^{\mathrm{a} b \mathrm{~b}}$ & - \\
\hline & B4 & - & - & - & $29.8 \pm 5.1^{\mathrm{b}, \mathrm{c}, \mathrm{d}}$ \\
\hline
\end{tabular}

Note: ${ }^{\mathrm{a}}-\mathrm{P}<0.05$ compared to baseline, ${ }^{\mathrm{b}}-\mathrm{P}<0.05$ compared to the $5-6$ th day of Alzheimer's disease, ${ }^{\mathrm{C}}-\mathrm{P}<0.05$ compared to the 16-17th day of Alzheimer's disease without treatment, ${ }^{\mathrm{d}}-\mathrm{P}<0.05$ compared to the familiar object (A1); the reliability of the differences between the samples was evaluated using the singlefactor dispersion analysis (ANOVA), using the Tukey test; $\mathrm{A} 1$ and $\mathrm{A} 2$ - familiar objects, B1, B2, B3, B4 - unfamiliar objects; “-”- - not investigated.

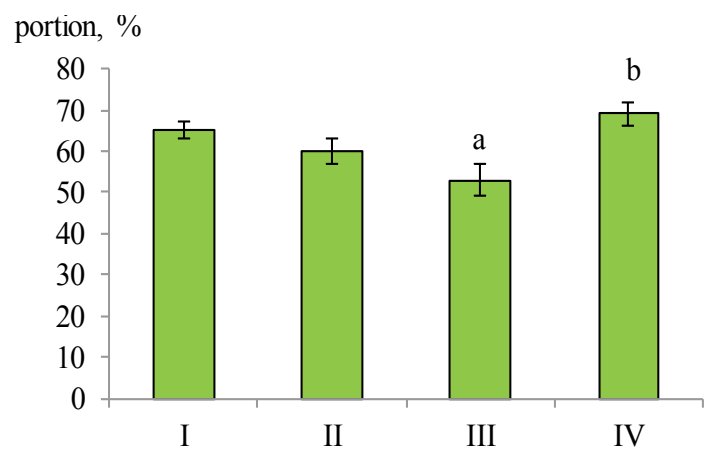

Fig. 3. Coefficient of discrimination in the test working memory in rats under the influence of intrahypocampal administration of aggregates of $\beta$-amyloid peptide 40 and intranasal administration of liposomal miR-101: I- baseline, II - model of Alzheimer's disease on the 6th day of the study, III - model of Alzheimer's disease on the 17th day of the study without treatment, IV - intranasal administration of liposomal miR-101 in Alzheimer's disease on the 17th day of the study; $\mathrm{x} \pm \mathrm{SD}, \mathrm{n}=33 ; \mathrm{a}-\mathrm{P}<0.05$ compared to the original data; $\mathrm{b}-\mathrm{P}<0.05$ compared with the 17 th day of Alzheimer's disease; here and in Figure 6 the reliability of the differences between the samples was evaluated using ANOVA

Intranasal administration of miR-101 in the form of liposomes reproduced the perception of new information on the study of identical objects and the differentiation of different shaped objects. Rats spent the same amount of time exploring similarly shaped objects. Objects that differed in shape aroused the interest of animals. The experimental activity significantly $(\mathrm{P}<0.05)$ increased compared with the indicators observed in the simulation of Alzheimer's disease (Table 1, Fig. 3).

Spatial memory. A study of short-term spatial memory in rats in the Barnes labyrinth showed that the introduction of $A \beta 40$ aggregates reduced the time spent at the opening of the protective chamber on both the 11th and 26th day of Alzheimer's disease simulation $(P<0.05$, Table 2$)$, i. e. in animals the forgetting of the location of the opening of the protective chamber was observed.

It should be noted that for rats under the conditions of testing, the entrance to the protective chamber was closed, which increased their search activity. There was a movement of rats in a circle with a consecutive longer study of false holes (Fig. 4). That is, at an early stage of Alzheimer's disease there was an inhibition of the process of extracting spatial information from the engram of memory and a partial violation of its reproduction. Intranasal course of liposomal miR-101 for 10 days in rats with an 
experimental model of Alzheimer's disease restored short-term spatial memory. A probable decrease in the search time for the protective chamber was revealed (Table 2). The animals immediately went to the protective chamber, examined the entrance to it, and the trajectory was similar to the original data, which indicated an improvement in the analytical processes of the rat brain under the influence of miR-101 (Fig. 4d).

\section{Table 2}

Influence of intrahypocampal administration of $\beta$-amyloid peptide 40 aggregates and intranasal administration of liposomal miR-101 on short-term spatial memory in rats in the Barnes labyrinth $(\mathrm{x} \pm \mathrm{SD})$

\begin{tabular}{|c|c|c|c|c|}
\hline $\begin{array}{l}\text { Characteristics } \\
\text { of the group }\end{array}$ & $\begin{array}{l}\text { Output } \\
\text { data }\end{array}$ & $\begin{array}{c}\text { Model of } \\
\text { Alzheimer's } \\
\text { disease }\end{array}$ & $\begin{array}{l}\text { The model of the } \\
\text { disease } \\
\text { Alzheimer's } \\
\text { without treatment }\end{array}$ & $\begin{array}{l}\text { Intranasal liposomal } \\
\text { administration } \\
\text { miR-101 in } \\
\text { Alzheimer's disease }\end{array}$ \\
\hline Date & Oth day & 11th day & 26th day & 26th day \\
\hline Group name & common & common & comparison & experimental \\
\hline $\mathrm{n}$ & 18 & 18 & 10 & 8 \\
\hline $\begin{array}{l}\text { Search time for } \\
\text { security chamber, } \mathrm{s}\end{array}$ & $8.5 \pm 1.8$ & $10.5 \pm 1.3$ & $10.7 \pm 4.0$ & $6.2 \pm 1.4^{\mathrm{b}}$ \\
\hline $\begin{array}{l}\text { Time spent near the } \\
\text { security chamber, } \mathrm{s} \\
\text { Number of }\end{array}$ & $22.1 \pm 2.0$ & $15.2 \pm 1.7^{\mathrm{a}}$ & $16.6 \pm 1.2^{\mathrm{a}}$ & $25.4 \pm 4.1^{\mathrm{b}, \mathrm{c}}$ \\
\hline $\begin{array}{l}\text { approaches to the } \\
\text { security chamber, } \\
\text { conventional units }\end{array}$ & $4.5 \pm 0.3$ & $4.8 \pm 0.7$ & $3.8 \pm 0.1$ & $4.5 \pm 0.2^{\mathrm{c}}$ \\
\hline
\end{tabular}

conventional units

Note: ${ }^{\mathrm{a}}-\mathrm{P}<0.05$ compared to baseline, ${ }^{\mathrm{b}}-\mathrm{P}<0.05$ compared to the 11 th day of Alzheimer's disease, ${ }^{\mathrm{c}}-\mathrm{P}<0.05$ compared to the 26th day of Alzheimer's disease without treatment; the reliability of the differences between the samples was evaluated using ANOVA.
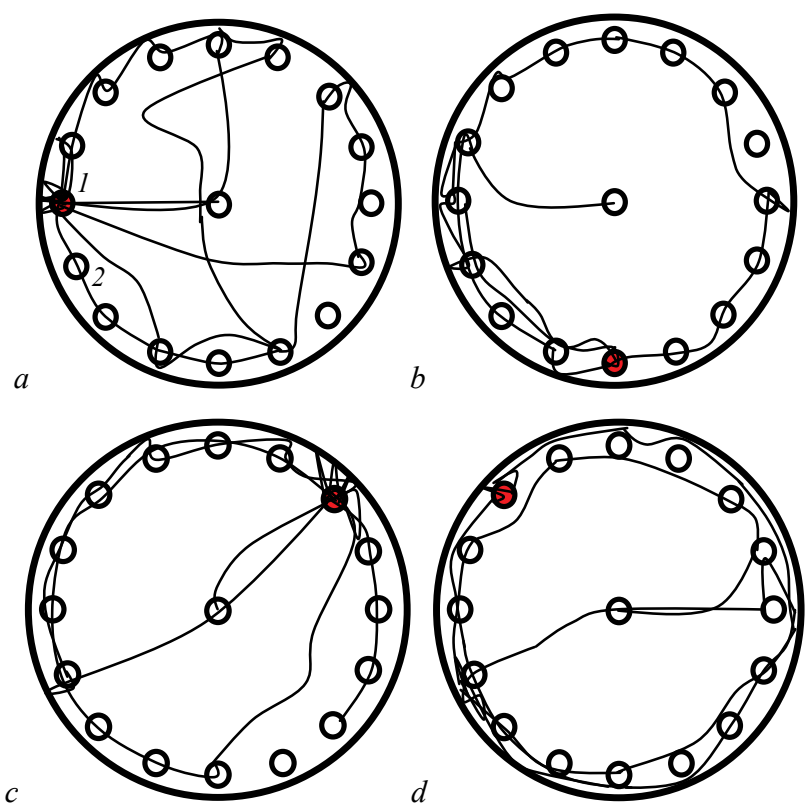

Fig. 4. The trajectories of rats in the Barnes labyrinth after intrahypocampal injection of $A \beta 40$ and intranasal injection of liposomal miR-101 (short-term spatial memory testing): $a$ - the original data of rats; $b-11$ th day after the introduction of $A \beta 40$ aggregates; $c$ - the 26th day after the introduction of $\mathrm{A} \beta 40 ; d-$ after 10 days of intranasal injection of liposomal miR-101, 1 - entrance to the protective chamber, 2 - false holes

When rats were tested for long-term spatial memory on the 7th day of Alzheimer's disease simulation, probable changes were found. The animals forgot the experience gained, a lot of time was spent searching for a protective chamber, sniffing fake holes. When compared with the initial data, the search time for the protective chamber and the number of approaches to it increased $(\mathrm{P}<0.05)$, and the time spent near the chamber decreased $(\mathrm{P}<0.05$, Table 3$)$.

Subsequently, on the 21st day after the introduction of $A \beta 40$ in rats, the violation of recognition of the familiar location of the protective chamber persisted. This was manifested in the chaotic movements of animals through the maze and ignoring of the opening to the protective chamber
(Fig. 5c). There was a probable decrease in the number of approaches to the security chamber. Intranasal administration to rats of the experimental group of liposomal miR-101 for 10 days restored memories of the location of the protective chamber. Animals of the experimental group spent a large amount of time near it, compared with rats of the comparison group (Fig. 5c, d).

\section{Table 3}

Effect of intrahypocampal administration of $\beta$-amyloid peptide 40 aggregates and intranasal administration of liposomal miR-101 on long-term spatial memory in rats in the Barnes labyrinth $(\mathrm{x} \pm \mathrm{SD})$

\begin{tabular}{lcccc}
\hline $\begin{array}{l}\text { Characteristics } \\
\text { of the group }\end{array}$ & $\begin{array}{c}\text { Output } \\
\text { data }\end{array}$ & $\begin{array}{c}\text { Model of } \\
\text { Alzheimer's } \\
\text { disease }\end{array}$ & $\begin{array}{c}\text { The model of the Intranasal liposomal } \\
\text { disease Alz } \\
\text { treatment }\end{array}$ & $\begin{array}{c}\text { administration } \\
\text { miR-101 in }\end{array}$ \\
\hline Date & Oth day & 7th day & 21st day & 21st day \\
\hline Group name & common & common & comparison & experimental \\
\hline $\mathrm{n}$ & 18 & 18 & 10 & 8 \\
\hline $\begin{array}{l}\text { Search time for } \\
\text { security chamber, } \mathrm{s}\end{array}$ & $8.5 \pm 1.8$ & $16.5 \pm 2.0^{\mathrm{a}}$ & $9.5 \pm 2.1$ & $12.0 \pm 2.5$ \\
$\begin{array}{l}\text { Time spent near the } \\
\text { security chamber, } \mathrm{s}\end{array}$ & $22.1 \pm 2.2$ & $14.0 \pm 3.0^{\mathrm{a}}$ & $16.4 \pm 4.6$ & $21.5 \pm 7.6$ \\
$\begin{array}{l}\text { Number of ap- } \\
\text { proaches to the } \\
\text { security chamber, } \\
\text { conventional units }\end{array}$ & $4.5 \pm 0.3$ & $3.9 \pm 0.3^{\mathrm{a}}$ & $3.2 \pm 0.1^{\mathrm{ab}}$ & $3.5 \pm 0.4$ \\
\hline
\end{tabular}

Note: ${ }^{\mathrm{a}}-\mathrm{P}<0.05$ compared to baseline, ${ }^{\mathrm{b}}-\mathrm{P}<0.05$ compared to the 7 th day of Alzheimer's disease; the reliability of the differences between the samples was evaluated using ANOVA.
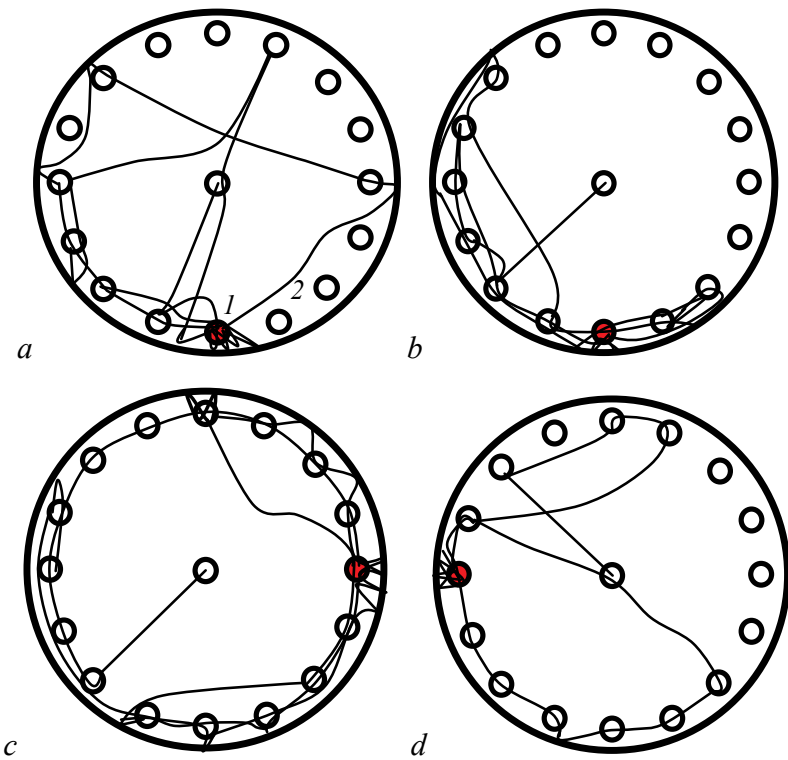

Fig. 5. The trajectories of rats of both groups in the Barnes labyrinth after intrahypocampal injection of $A \beta 40$ and intranasal injection of liposomal miR-101 (long-term spatial memory testing): $a$ - the original data of rats; $b-7$ th day after the introduction of A $\beta 40 ; c-21$ st day after the introduction of A $\beta 40 ; g$ - after 10 days of intranasal administration of liposomal miR-101; 1 - entrance to the security chamber, 2 - fake holes

Emotional memory. Studies in rats of emotional memory using the conditioned reflex response of stimulus avoidance found that the quantitative and temporal rates of stable conditioned reflexes to avoid the negative stimulus during intrahypocampal administration of $A \beta 40$ aggregates did not change, compared with the rates of conditioned reflexes to. Thus, the latent periods of conditioned reflex responses on the 5th day of Alzheimer's disease simulation were $8.1 \pm 0.4 \mathrm{~s}$ against the indicators before the introduction of neurotoxin $8.5 \pm 1.3 \mathrm{~s}$, the number of conditioned reflex responses was $76.9 \pm 10.4 \%$ against $72.2 \pm 10.1 \%$, respectively. However, the severity of the manifestations of inter-signal reactions changed. There was an increase in the proportion of signaling reactions from $15.4 \pm$ $4.3 \%$ to $29.6 \pm 5.9 \%$, which reflected a violation of the structure of behaviour in the animals, both at the stage of afferent synthesis and at the stage 
of decision making, which was probably associated with processing of afferent information, the formation of dominant motivation (Fig. 6). In addition, the rats again had reactions to the samples, as an indicator of indecision in the performance of conditioned reflex reactions and violation of mechanisms in the acceptor of the result of the action of Anokhin (1968). A probable increase in the number of unconditional avoidance and grooming reactions $(\mathrm{P}<0.05)$, along with an increase in autonomic reactions (urination, defecation) indicated an increase in anxiety and distress (Fig. 6).

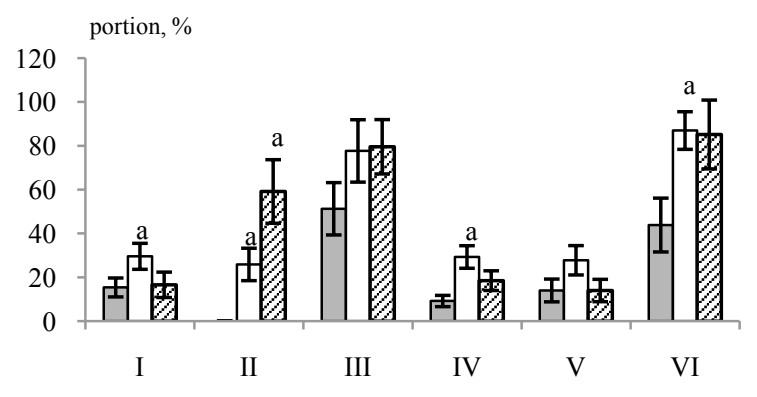

Fig. 6. Change in intersignal responses in rats after simulation of Alzheimer's disease and intranasal administration of liposomal miR-101: $\square$-initial data of rats, $\square$-model of Alzheimer's disease (5th day after administration of $A \beta 40$ aggregates), $\square$ - after 10 days of treatment with liposomal miR-101 Alzheimer's disease; inter-signal reactions: I - signal reactions, II - sample reactions, III - extra-signal reactions, IV - unconditional avoidance reactions, $\mathrm{V}$ - vegetative manifestations, $\mathrm{VI}$ - grooming; $\mathrm{x} \pm \mathrm{SD}, \mathrm{n}=9{ }^{\mathrm{a}}{ }^{\mathrm{a}}-\mathrm{P}<0.05$ compared with the original data of rats, see Figure 3

Intranasal administration of liposomal miR-101 did not affect the conditioned reflex activity of rats (Fig. 6), but led to the removal of emotional stress in the implementation of conditioned reflex reactions to actively avoid pain stimuli.

\section{Discussion}

The cognitive impairments that accompany neurodegenerative agerelated diseases are an urgent medical problem today. Animal models are widely used to study the pathogenesis of these diseases, neurobehavioral disorders and the effectiveness of therapy (Zhang et al., 2012; Wahl et al., 2017). Memory impairment is a specific feature of Alzheimer's disease, so the study of associative learning, learning with a change in spatial orientation, working, spatial and emotional memory is an important tool for determining cognitive dysfunction, the establishment of pathogenetic mechanisms and the choice of treatment (Webster et al., 2014; Bengoetxea et al., 2015; Zarifkar, 2019). Among the behavioral tests for the study of cognitive impairment in Alzheimer's disease, the most notable are neurobehavioral tests, which are associated with clinical manifestations of memory impairment in humans. The tests used in our study relate to object recognition (working memory), which excludes rewards or penalties (Bengoetxea et al., 2015) and spatial orientation (spatial memory) (Mugantseva, 2010; Webster et al., 2014).

Changes in working, spatial and emotional memory in rats caused by intrahypocampal administration of $\beta$-amyloid peptide 40 aggregates, are associated with impaired storage and retrieval of information about the experience due to dysfunction of brain structures - hippocampus and anterior neocortex, which agrees with the data (Mugantseva \& Podolski, 2009) on the weakening of the interneuronal connections between the hippocampus and the neocortex under the action of aggregated $\beta$-amyloid peptide. Earlier Sokolik et al. (2019) showed that the introduction of A $\beta 40$ aggregates into the hippocampus leads to an increase in the concentration of toxic endogenous $A \beta 42$ by $36.2 \%$ in the neocortex and $27.3 \%$ in the hippocampus. This increase in the concentration of toxic $\beta$-amyloid peptide 42 is characteristic of the development of preclinical and early clinical stages of Alzheimer's disease, when the clinical manifestations of the disease are compensated by brain mechanisms (Purdenko, 2014). Therefore, our model allows us to consider it as adequate for the study of early manifestations of memory disorders in Alzheimer's disease. It should be noted that the detected memory impairments depend not only on the length of time the information is stored - short-term or long-term memory, but also on the type of memory. The most demonstrative were violations of the components of short-term and long-term spatial memory, in terms of finding the location of the protective chamber. It has been shown that spatial memory impairment in patients with Alzheimer's disease is associated with impaired interspheric information (Delbeuck et al., 2003). Working memory, as a process of storing information during the experiment, also changed: violations of the differentiation of the shape of objects and decision-making were found.

It is known that the mechanisms of memory are closely related to emotions, their morpho-functional substrate is the limbic-neocortical system of the brain (Vinogradova, 1975; Makarenko, 1980). However, we did not detect emotional memory impairment with the use of the classical conditioned reflex reaction of active avoidance of the pain stimulus at an early stage in the development of experimental Alzheimer's disease. It is clear that the innate forms of protective and adaptive behaviour in this period of the disease are preserved. However, there were manifestations of behavioral components that accompany conditioned reflex responses. These are test reactions, unconditional avoidance reactions and autonomic reactions - urination and defecation, which can be assessed as an increase in anxiety.

Recently, researchers have focused on finding approaches to inhibit amyloidogenesis in Alzheimer's disease by influencing the molecular mechanisms of $\beta$-amyloid peptide formation at the posttranscriptional level. In this regard, noteworthy are small non-coding RNA molecules miRNAs, which are involved in the regulation of gene expression, differentiation, proliferation and apoptosis of cells (Siegel et al., 2011; Olde Loohuis et al., 2012). MicroRNA inhibits gene expression in two ways: by interaction with template RNA or excludes the gene due to epigenetic modulation of the genome. It has been shown that miR-101 microRNA is able to inhibit the synthesis of $\beta$-amyloid peptide precursor protein (A $\beta \mathrm{PP})$ at the stage of its translation. This leads to the elimination of the accumulation of excess $\mathrm{A} \beta \mathrm{PP}$ and its processing in the amyloidogenic scenario (Vilardo et al., 2010; Amakiri et al., 2019).

Intranasal administration of miR-101 in liposomal form to rats with a model of early manifestations of Alzheimer's disease led to the improvement of short-term spatial memory, the effectiveness of which was determined by the reproduction of components (skills) of spatial orientation. The improvement in working memory was manifested in the restoration of the level of research activity of rats and the differentiation of familiar and unfamiliar objects. Apparently, the positive effects of miR-101 when introduced into the body in liposomal form are due to their intranasal delivery to the target brain structures of the hippocampus and neocortex and the regulatory effect on the processes of amyloidosis.

\section{Conclusion}

Intranasal administration of miR-101 in liposomal form to late adult rats with an experimental model of Alzheimer's disease, resulting from the introduction of $\beta$-amyloid peptide 40 aggregates into the hippocampus, improves working and spatial memory: restores the level of research activity objects; increases the efficiency of spatial memory due to the reproduction of spatial orientation skills; improves the emotional state of rats in the implementation of conditioned reflex reactions of active avoidance of painful stimuli.

\section{References}

Abdurasulova, I. N., Ekimova, I. V., \& Chernyshjov, M.V. (2019). Narusheniye kognitivnykh funktsiy u krys Vistar v modeli doklinicheskoy stadii bolezni Parkinsona [Cognitive impairment in Wistar rats in a model of the preclinical stage of Parkinson's disease]. Zhurnal Vysshey Nervnoy Deyatel'nosti, 69(3), 364-381 (in Russian).

Amakiri, N., Kubosumi, A., \& Tran, J. (2019). Amyloid beta and MicroRNAs in Alzheimer's disease. Frontiers in Neuroscience, 13, 430.

Anokhin, P. K. (1968). Biologiya i neyrofiziologiya ulovnogo refleksa [Biology and neurophysiology of the catch reflex]. Mediczina, Moscow (in Russian). 
Antunes, M., \& Biala, G. (2012). The novel object recognition memory: Neurobiology, test procedure, and its modifications. Cognitive Processing, 13, 93-110.

Attar, A., Liu, T., \& Chan, W.-T. C. (2013). A shortened barnes maze protocol reveals memory deficits at 4-months of age in the triple-transgenic mouse model of Alzheimer's disease. PLoS One, 8(11), e80355.

Bengoetxea, X., Rodriguez-Perdigon, M., Ramirez, M. J. (2015). Object recognition test for studying cognitive impairments in animal models of Alzheimer's disease. Frontiers in Bioscience, 7, 10-29.

Bevziuk, D. O., Levicheva, N. O., \& Sokolik, V. V. (2020). Osoblyvosti porushen' pam'yati na ranniy stadiyi rozvytku khvoroby Altsheymera u shchuriv [Features of memory disorders in the early stages of Alzheimer's disease in the rats]. Physiological Journal, 66(1), 68-74 (in Ukrainian).

Bullock, R. (2002). New drugs for Alzheimer's disease and other dementias. The British Journal of Psychiatry, 180(2), 135-139.

Buresh, Y., Petran, M, \& Zakhar, I. (1962). Elektro-fiziologicheskiye metody issledovaniya [Electro-physiological research methods]. Izdatel'stvo Inostrannoj Literatury', Moscow (in Russian).

Delbeuck, X., Van der Linden, M., \& Collette, F. (2003). Alzheimer's disease as a disconnection syndrome? Neuropsychology Review, 13, 79-92.

Eisenstein, M. (2019). Pharma's roller-coaster relationship with RNA therapies. Nature, 574, 10-16.

Francis, P. T., Ramirez, M. J., \& Lai, M. K. (2010). Neurochemical basis for symptomatic treatment of Alzheimer's disease. Neuropharmacology, 59, 221-229.

Grigorchuk, O. S. (2013). Rol' neyronov dorsal'nogo gippokampa v mekhanizmakh formirovaniya razlichnykh emotsional'no-motivatsionnykh sostoyaniy u krys: Effekty peptida del'ta-sna [The role of dorsal hippocampal neurons in the mechanisms of formation of various emotional and motivational states in rats: Effects of the delta sleep peptide]. Moscow (in Russian).

Guljaev, S. M., Taraskin, V. V., \& Radnaeva, L. D. (2017). Antiamnesticheskiy effekt ekstrakta vzdutoplodnika sibirskogo pri skopolamin-indutsirovannoy amnezii [Anti-amnestic effect of the Siberian baffle extract with scopolamine-induced amnesia]. Obzory po Klinicheskoy Farmakologii i Lekarstvennoy Terapii, 15(4), 53-54 (in Russian).

Huijgen, J., \& Samson, S. (2015). The hippocampus: A central node in a large-scale brain network for memory. Revue Neurologiqu (Paris), 171(3), 204-216.

Insel, N., \& Takehara-Nishiuchi, K. (2013). The cortical structure of consolidated memory: A hypothesis on the role of the cingulate-entorhinal cortical connection. Neurobiology of Learning and Memory, 106(7), 343-350.

Makarenko, U. A. (1980). Sistemnaya organizatsiya emotsional'nogo povedeniya [Systemic organization of emotional behavior]. Mediczina, Moscow (in Russian).

Mugantseva, E. A. (2010). Issledovaniye prostranstvennoy pamyati i spektral'nokorrelyatsionnykh kharakteristik EEG gippokampa i frontal'noy kory na modeli bolezni Altsgeymera [The study of spatial memory and spectralcorrelation characteristics of the EEG of the hippocampus and frontal cortex on a model of Alzheimer's disease]. Pushchino (in Russian).

Mugantseva, E. A., \& Podolski, I. Y. (2009). Animal model of Alzheimer's disease: Characteristics of EEG and memory. Central European Journal of Biology, 4(4), 507-514.

Mukhin, V. (2013). Patogeneticheskie mehanizmyi disfunktsii bazalnoy holinergicheskoy sistemyi pri bolezni Altsgeymera [Pathogenesis of the basal forebrain cholinergic dysfunction in Alzheimer's disease]. Rossijskii Fiziologicheskij Zhumal imeni I. M. Sechenova, 99(7), 793-804 (in Russian).

Olde Loohuis, N. F., Kos, A., \& Martens, G. J. (2012). MicroRNA networks direct neuronal development and plasticity. Cellular and Molecular Life Sciences, 69, 89-102.
Purdenko, T. I. (2014). Problema kognityvnykh rozladiv u nevrologichnij praktyci (oglyad literatury) [The problem of cognitive impairment in neurological practice (reference review)]. Bukovinian Medical Herald, 18(4), 216-221 (in Ukrainian).

Raven, F., Ward, J. F., \& Zoltowska, K. M. (2017). Soluble Gamma-secretase modulators attenuate Alzheimer's $\beta$-amyloid pathology and induce conformational changes in presenilin 1. EBioMedicine, 24, 93-101.

Shaik, M. M., Tamargo, I. A., \& Abubakar, M. B. (2018). The role of microRNAs in Alzheimer's disease and their thera-peutic potentials. Genes (Basel), 9(4), 174.

Shulga, S. M. (2014). Obtaining and characteristic of curcumin liposomal form Biotechnologia Acta, 7(5), 55-61

Siegel, G., Saba, R., \& Schratt, G. (2011). MicroRNAs in neurons: Manifold regulatory roles at the synapse. Current Opinion in Genetics and Development, 21, 491-497.

Silachjov, D. H., Shram, S. I., \& Shakova, F. M. (2008). Formirovanie prostranstvennoj pamjati u krys s ishemicheskim povrezhdeniem prefrontal'noj kory mozga: effekty sinteticheskogo analoga AKTG [The formation of spatial memory in rats with ischemic damage to the prefrontal cortex: effects of a synthetic analogue of ACTH]. Zhumal Vysshei Nervnai Deiatelnosti I. P. Pavlova, 58(4), 458 466 (in Russian)

Sokolik, V. V., Berchenko, O. G., \& Shulga, S. M. (2017). Comparative analysis of nasal therapy of curcumin soluble and liposomal forms of rats with mode of Alzheimer's disease. Journal of Alzheimer's Disease and Parkinsonism, 7(4), 1000357

Sokolik, V. V., Berchenko, O. H., \& Levicheva, N. V. (2019). Anti-amyloidogenic effect of miR-101 in experimental Alzheimer's disease. Biotechnologia Acta, 12(3), 41-49.

Sysoev, U. I. (2019). Mekhanizm dejstvija novogo proizvodnogo etanolamina bis $\{2-[(2 \mathrm{e})-4$-gidroksi-4-oksobut-2-enoiloksi]-N, N-dietiletanamonija\} butandionata [The mechanism of action of a new derivative of ethanolamine - bis (2(2e)-hydroxy and oxobut-2-enoxy-n n-diethyl ethanolammonium butanedione] Eksperimental'naja i Klinicheskaja Farmakologija, 82(4), 3-10 (in Russian).

Tzyy-Nan, H., \& Yi-Ping, H. (2014). Novel object recognition for studying memory in mice. Neuroscience, 19, 1-7.

Vilardo, E., Barbato, C., \& Ciotti, M. (2010). MicroRNA-101 regulates amyloid precursor protein expression in hippocampal neurons. Journal of Biological Chemistry, 285, 18344-18351.

Vinogradova, O. S. (1975). Gippokamp i pamyat' [Hippocampus and memory]. Nauka, Moscow (in Russian).

Wahl, D., Coogan, S., \& Couter, D. (2017). Cognitive and behavioral evaluation of nutritional interventions in rodent models of brain aging and dementia. Clinical Interventions in Aging, 12, 1419-1428.

Wang, W., Kwon, E. J., \& Tsai, L.-H. (2012). MicroRNAs in learning, memory, and neurological diseases. Learning Memory, 19, 359-368.

Webster, S. J., Bachstetter, A. D., \& Eldik, L. J. (2014). Using mice to mode Alzheimer's dementia: An overview of the clinical disease and the preclinical behavioral changes in 10 mouse models. Frontiers in Genetics, 5, 88.

Zarifkar, A. H., Zarifkar, A., \& Bagheri, F. V. (2019). Ameliorative effects of different transcranial electrical stimulation paradigms on the novel object recognition task in a rat model of Alzheimer disease. Galen Medical Journal, e1440.

Zhang, R., Xue, G., \& Xie, X. (2012). Novel object recognition as a facile behavior test for evaluating drug effects in A $\beta \mathrm{PP} / \mathrm{PS} 1$ Alzheimer's disease mouse model. Journal of Alzheimer's Disease, 31(4), 801-812. 